This is a self-archived version of an original article. This version may differ from the original in pagination and typographic details.

Author(s): Karjaluoto, Heikki; Paakkonen Lasse

Title: An empirical assessment of employer branding as a form of sport event sponsorship

Year: 2019

Version: Accepted version (Final draft)

Copyright: @ 2019 Emerald Publishing Limited

Rights: In Copyright

Rights url: http://rightsstatements.org/page//nC/1.0/?language=en

Please cite the original version:

Karjaluoto, Heikki, Paakkonen Lasse. (2019). An empirical assessment of employer branding as a form of sport event sponsorship. International Journal of Sports Marketing and Sponsorship, 20(4), 666-682. https://doi.org/10.1108/ijsms-10-2018-0103 


\section{An Empirical Assessment of Employer Branding as a Form of Sport Event Sponsorship}

Abstract

Purpose - The goal of this study is to expand and test Backhaus and Tikoo's (2004) employer branding conceptual framework from the perspective of internal employer branding in a sport event sponsorship context.

Design/methodology/approach - This study developed a set of hypotheses, which were tested in the context of a business-to-business multinational organization's sport event sponsorship project. Empirical data were collected from 716 employees of the case company after the sponsorship project was complete.

Findings - The results support all the hypotheses and reveal that a sport event sponsorship project can act as a means to achieving employer branding goals in the investigated context.

Research limitations/implications - The sample of the study was limited to the existing personnel of one case company. The study measures the effects at a single point in time, thus the findings should be validated with longitudinal research design.

Practical implications - The results propose that companies can benefit from integrating sport sponsorship with internal employer branding. Practitioners are advised to create sponsorship projects that involve current employees effectively.

Originality/value - Our study adds to the literature by being among the first empirical studies to have tested the effects of employer branding among current employees via a sponsorship project.

Keywords - Employer branding, Sport sponsorship, Organizational identity, Organization culture, Employer brand association, Employer attraction

Type - Research paper

Introduction 
In today's rapidly changing competitive markets, companies must constantly respond to increasing demands for a highly talented workforce (Chhabra and Sharma, 2014). The simultaneous ascent of burgeoning economies is also increasing the competition for a skilled workforce (Chambers et al., 1998). Therefore, it is crucial for companies to generate strategies and operations to attract potential talent and retain their current employees (Chhabra and Sharma, 2014). Developing an employer brand is an effective method for managing this vital area in today's challenging markets (Moroko and Uncles, 2008).

Attraction, recruitment, and retention of the best talent have always been challenging for organizations. Over the past decade, companies from various industries (e.g., Siemens and Coca Cola) have striven to build successful brand management to ensure their competitiveness in different business environments. Improving an employer's brand is an effective method for attracting and retaining the most talented workforce to subsequently secure the brand's success. Notably, firms that embrace employer branding (EB) can gain a competitive edge (Moroko and Uncles, 2008); thus, EB is an effective method for helping companies differentiate themselves from other employers who are competing for the same talented workforce (Backhaus and Tikoo, 2004).

Academics and practitioners began showing significant interest in understanding the effectiveness of EB in recent years. Even though branding is a developed concept in both the marketing literature and in practice, perspectives of EB are still evolving (Backhaus and Tikoo, 2004; Theurer et al., 2018). Earlier research has primarily focused on the examination of EB as a phenomenon from the conceptual perspective, and empirical studies on the topic are almost non-existent (Moroko and Uncles, 2008). Additionally, recent empirical research has focused on the external effects of EB, such as recruitment processes (Bisvas and Suar, 2016). Still, little is known about EB from the internal perspective of companies, such as what attributes make an employer's brand attractive to current employees (Maxwell and Knox, 2009). 
The objective of this study is to examine the impacts of EB on employees' perceptions of the company as an employer via a sport sponsorship relationship between a business-to-business multinational company (hereafter "the case company") and a sporting event (the 2017 Nordic Skiing World Championships in Lahti) from the perspective of the case company's current employees. This study thus responds to the call for empirical research on EB from the internal perspective of organizations (Maxwell and Knox, 2009). Desirable outcomes of EB for the case firm include improved employer image, employer attraction, and improvements in employees' satisfaction, commitment, and productivity. The results of this study will increase the current understanding of the effectiveness and impacts of EB and consequently help shape employer brand into a more attractive form in the future.

\section{Literature review}

\section{Employer branding}

For companies, brands are seen as the most valuable assets, while employees are the most important resources (Ambler and Barrow, 1996). Brand management is the key activity in companies' business operations, and employees have an increasing role in the success as well as the evolution of an organization's brand (Backhaus and Tikoo, 2004).

Per Theurer et al. (2018), it is important to make a distinction between employer brand and EB (employer branding). Employer brand refers to "the package of functional, economic, and psychological benefits provided by employment and identified with the employing company" (Ambler and Barrow, 1996, p. 187). It consists of exquisite features of the company's employment offerings and environment (Backhaus and Tikoo, 2004). EB instead relates to the process of building the employer's identity/image. Thus, EB is understood as an umbrella under which both marketing activities and human resources (HR) management reside. It is a moderately new approach in the academic literature. As a research discipline, EB was initially 
introduced by Ambler and Barrow (1996), who executed an exploratory study amongst UK companies to investigate whether marketing tools and brand management are beneficial in employment situations. Despite some empirical resistance to the introduction of marketing tools and practices, the authors concluded that marketing tools and HR management, when used together, can create the concept of employer brand. These results indicate that EB projects yield important benefits, such as higher retention rates of current employees and increased employer attraction from the perspective of potential talent.

EB is a process in which marketing tools, communication, and HR management are applied to create a brand (Martin et al., 2011). These marketing tools, such as corporate branding, internal marketing, relationship marketing, and corporate reputation, are linked to HR management concepts, such as recruitment processes and organizational behavior (Moroko and Uncles, 2008). EB has both internal and external dimensions. Internal EB aims to impact firms' current employees, whereas external EB focuses on attracting potential talent. EB naturally also aims to differentiate a firm in a positive way from other companies as an employer (Backhaus and Tikoo, 2004).

\section{Internal employer branding}

EB has the same elements as internal branding, and both concepts relate to organizations' current employees. Internal branding consists of three functions: a) effective communication of the brand to employees, b) convincing employees of the brand's relevance and worth, and c) linking every job in the company to successful brand delivery (Berthon and Ewing, 2005). Internal EB affects current employees' brand loyalty toward the employer (Backhaus and Tikoo, 2004). In general, EB is a tool that companies can use to deliver key brand messages to internal stakeholder groups in the organization. 
Employee satisfaction and loyalty have been identified as critical goals for EB (Backhaus and Tikoo, 2004). Companies with loyal and satisfied employees have a high retention rate (Heskett et al., 1994), and their employees often share positive information about the company to both internal and external audiences (Chambers et al., 1988). This increases the attractiveness of the employer and leads to a better reputation from the perspective of prospective employees (Moroko and Uncles, 2008).

\section{Internal sponsorship relationships}

In addition to achieving external objectives, such as brand awareness, sponsorship also affects the internal audience, such as an organization's current employees (Cunningham et al., 2009). Farrelly and Greyser (2007, p. 24) stated that "Sports-related internal communications can create cohesion, elicit pride in the company, and enhance perceptions of it as a vibrant 'winner' or leader in its industry." Sponsorship activities enable companies to develop a positive organizational culture and improve their corporate and employer images from the perspective of employees. Moreover, successful sponsorship projects improve employees' morale, increase corporate pride, refresh corporate perceptions, and develop a sense of shared enterprise (Meenaghan et al., 2013).

Identification with a sponsorship target (e.g., a specific team or event) has a favorable relation with organizational identification and employees' organizational commitment, and it can increase employees' willingness to satisfy customers' needs (Hickman et al., 2005). Per Olejniczak and Aicher (2010), the most effective indicator of organizational identification is the perceived prestige of the sponsorship target. Internal impacts are also essential for EB strategies. Therefore, sponsorship can potentially help achieve EB goals.

Research model 
We build our research model on Backhaus and Tikoo's (2004) conceptual model that incorporates marketing and human resource concepts. Their model illustrates a process in which EB is seen as vital to developing employer attraction (external audience) and employee productivity (internal audience). EB creates two principal assets: In the external processes, brand associations are the main asset and the determinant of employer image, which in turn leads to greater employer attractiveness; in the internal process, employer brand loyalty is a principal asset, which acts as a determinant of employee productivity. Brand loyalty is built from both organizational culture and organizational identity. As our study aims to investigate only the internal impacts of EB, the factors that were originally suggested to explain external impacts (e.g., employer attraction) were adapted to the internal context in this study. Hence, this study investigates the case company's current employees' perceptions of employer brand association, employer image, and employer attraction.

Against this backdrop, we propose and test a model that measures the effects of EB inside an organization. The model (Figure 1) suggests that the EB project, which consists of sponsorevent fit and project communication quality, affects employer brand associations, organizational identity, and organizational culture. In addition, employer brand association is hypothesized to have a positive influence on employer image, which in turn affects employer attraction. This attraction, along with organizational culture and identity, relates to employees' overall satisfaction. Finally, it is proposed that satisfaction relates to higher employee commitment, which in turn leads to higher employee productivity.

"Take in Figure 1 about here"

\section{Organizational identity and culture}

Organizational identity has a strong connection to the EB concept (Backhaus and Tikoo, 2004). Dutton et al. (1994) argued that organizational identity consists of a collective attitude of the 
members of a company and their thoughts regarding the organization as a group. Employees have a desire to identify themselves with their company. Therefore, if organizational identity is perceived attractive, members will make that identification (Dutton et al., 1994).

Organizational culture consists of a firm's general assumptions and values, which members of the organization teach to new employees (Ravasi and Schultz, 2006). Deshpande and Webster (1989, p. 4) defined it as "the pattern of shared values and beliefs that help members of an organization understand why things happen and thus teach them the behavioral norms in the organization."

\section{Employer brand association, employer brand image, and employer attraction}

Brand associations are the thoughts and ideas that the brand name arouses in the minds of consumers (Aaker, 1991). Employees and prospective talent create their perceived employer brand associations via EB processes. Additionally, information sources (such as media and word-of-mouth) that are not managed by the company might affect perceived associations (Keller, 1993).

Brand image is related to either product or non-product attributes, and it contains functional and symbolic benefits that describe elements of employment with that firm (Keller, 1993). Employer brand image as a concept has the same elements as brand image, with the only difference being that employer brand image is directed toward employment situations. Functional elements of the employer brand include objective terms, such as salary, benefits, and contributions (Backhaus and Tikoo, 2004). These terms are desirable attributes that affect employees' perceptions of the employer. Symbolic elements of the employer brand encompass employees' perceptions about the prestige of the firm (Backhaus and Tikoo, 2004). 
Berthon et al. (2005, p. 156) defined employer attraction as "the envisioned benefits that a potential employee sees in working for a specific organization." Employer attraction is a desirable objective of EB processes; the more attractive an employer, the stronger the organization's employer brand (Backhaus and Tikoo, 2004).

Job satisfaction, employer brand loyalty, and employee productivity

Job satisfaction refers to positive emotions toward a certain job (Mueller et al., 1992). Based on Herzberg et al.'s (1957) classification, job satisfaction consists of two main dimensions: hygiene and motivation. Hygiene issues, such as salary and working conditions, relate to an employee's working environment. Although hygiene issues have no direct impact on satisfaction, and they do not motivate employees, they do have a connection to employee dissatisfaction. Motivators, such as the work itself and recognition, generate employee satisfaction toward the work environment by meeting individuals' needs for meaning and personal growth.

In the employment context, brand loyalty refers to employees' commitment to and willingness to stay with their employer (Backhaus and Tikoo, 2004). Per Meyer and Herscovitch (2001, p. 301), commitment is "a force that binds an individual to a course of action that is of relevance to a particular target." In this study, employee productivity, which is also known as employee performance, refers to employees' subjective evaluations of how effectively and productively they perform their jobs.

\section{Hypotheses development}

Backhaus and Tikoo's (2004) framework proposes that EB has positive effects on employer brand associations, organizational identity, and organizational culture. The EB construct in our study refers to two constructs: sponsor-event fit and the sponsorship project communication 
quality. Per Speed and Thompson (2000, p. 230), sponsor-event fit refers to the "attitude toward the pairing of event and sponsor and the degree to which the pairing is perceived as well matched or a good fit." Their study confirmed the positive effects of sponsor-event fit on sponsorship response when measured as interest, favorability, and use. Marketing literature and sports marketing literature widely confirm the positive outcomes (such as increased awareness and more positive attitudes toward the brand/product/event) of consumers' affiliation with the sponsored entity (Hermann et al., 2016; Kim and $\mathrm{Na}, 2008$ ). Backhaus and Tikoo (2004) in turn proposed that EB reinforces organizational culture and strengthens organizational identification among employees. Building on the above, we aim to test these effects in the internal EB context and thus hypothesize the following:

H1: Sponsor-event fit in the EB project will positively influence organizational culture.

H2: Sponsor-event fit in the EB project will positively influence organizational identity. Regarding the effectiveness of internal communication (in this case, communication of the project to the employees), it is well known that communication is a key driver of employee engagement (Kahn, 1992; Kress, 2005; Kang and Sung, 2017). Internal corporate communication has been defined as "organizational practices designed to promote employee understanding of the goals of the organization and enable them to identify with the values of the organization" (Welch, 2001, p. 339). The success or failure of internal communication often stems from management's communication abilities (Wiley et al., 2010). On this basis, it is proposed that sponsor-event fit and employees' evaluations of the sponsorship project's internal communication affect their evaluations of their organization's culture and identity.

H3: Project communication quality in an EB project will positively influence organizational culture.

H4: Project communication quality in an EB project will positively influence organizational identity. 
EB plays a strong role in engendering the desired employer brand associations. Employees and prospective talent create their perceived employer brand associations via EB processes. Thus, employer brand association is the result of EB (Backhaus and Tikoo, 2004), and we propose the following:

H5: Sponsor-event fit in an EB project will positively influence employer brand associations from the perspective of current employees.

H6: Project communication quality in an EB project will positively influence employer brand associations from the perspective of current employees.

Brand associations affect employer brand image (Bisvas and Suar, 2016). For instance, Keller (1993) argued that the perceived value of the brand image is influenced by brand associations in a person's mind. Employer brand image has a positive relation to employer attractiveness (Gatewood et al., 1993) because it affects attraction, which in turn relates to the PeopleOrganization (P-O) fit concept. Kristof (1996, p. 6) defined P-O fit as "the compatibility between people and organizations that occurs when either (a) at least one entity provides what the other needs or (b) they share similar fundamental characteristics or (c) both." This theory consists of claims that potential employees have needs, personalities, and values, and they assimilate these to the employer brand image that they have created. The stronger the match between an employer and employees' values, the higher the attraction level of the organization from the perspective of employees (Judge and Cable, 1997).

P-O fit has a relationship with employees' work-related attitudes (Chapman et al., 2005), including satisfaction with their employer (Kristof-Brown et al., 2005). Increased P-O fit will increase employees' job satisfaction (Verquer et al., 2003), whereas poor P-O fit leads to declines in overall job satisfaction (Wheeler et al., 2005). Therefore, the following hypotheses were created: 
H7: Employer brand associations will positively influence employer brand image from the perspective of current employees.

H8: Employer brand image will positively influence employer attraction.

H9: Employer attraction will positively influence employees' job satisfaction.

The relationship between organizational culture and job satisfaction has been the focus of several previous studies (Arnold and Spell, 2006; Jian and Klen, 2000; Mckinnon et al., 2003). These studies supported the positive relationship between the two concepts. Nystrom (1993) additionally found that strong organizational culture positively impacts employee job satisfaction. On this basis, the following hypotheses are proposed:

H10: Organizational culture will positively influence employees' job satisfaction.

H11: Organizational identity will positively influence employees' job satisfaction. Job satisfaction has been widely identified as a significant influencer of organizational commitment (Fu and Deshpande, 2014). Syptak et al. (1999) found that satisfied employees tend to be more productive, creative, and committed to their employers than those who are dissatisfied. In addition, employee job satisfaction is connected to productivity. For example, Miller and Monge (1986) stated that highly satisfied employees are motivated, which subsequently increases productivity. Organizational culture also has a connection with productivity. Hellriegel et al. (1998) stated that successful and effective companies have an organizational culture that stimulates involvement in important activities, such as decision making, goal setting, and problem solving. In addition, they proposed that encouraging a culture that affects employee involvement in a company's daily activities can influence an employee's performance (Hellriegel et al., 1998). On this basis, we propose the following:

H12: Employee job satisfaction toward the employer will positively influence organizational commitment. 
Employee commitment levels correlate with job satisfaction, productivity, and organizational performance (Ali et al., 2010). From the perspective of the employer, employee commitment toward the organization is highly important and critical to the company's functions. From the perspective of employees, it is also important to gain a strong and committed relationship with the employer. One reason could be that employees might think that their expertise in a specific job would not be in demand at either another company or in the employment market in general (Scholl, 1981). In addition, repeatedly changing one's employment situation may damage his/her reputation as a stable and loyal employee (Staw, 1981).

A positive relationship between employee commitment and productivity has been confirmed (Deepa et al., 2014). Per Woodman (1989), employees should be committed to an organization to make task designs, technology, structure, and strategies work productively, and Pasmore and Fagans (1992) argued that employee commitment determines the effectiveness of the organization. Therefore, the following is hypothesized:

H13: Employee organizational commitment will positively influence employee productivity.

\section{Methodology}

\section{Study setting}

Data were collected in relation to the 2017 Nordic Skiing World Championships in Lahti, where the case company (a multinational B2B firm) acted as the main sponsor of the event. The case company was sponsoring the event and conducting EB activities, such as bringing 5,000 of its current employees to the event. The case company was interested in developing its current employees' perceptions of the company as an employer. In this study, this sport sponsorship project acted as an EB activity that aimed to affect employee opinions toward the case company as an employer. In practice, the employees, on average, spent up to one week in Lahti and 
watched the competitions while wearing similar company-sponsored vests. Thus, all the employees were easily identified by other employees and by other spectators. The case company also organized daily events for the employees, such as speeches by the CEO and other management personnel. Overall, the event served to strengthen ties between employees of the firm by establishing new connections between those unknown to each other and by enriching previously established relationships.

\section{Data collection}

To test the hypotheses, an e-mail containing the link to the survey was sent to the case company's selected current employees $(\mathrm{N}=3,200)$ in February 2017, directly after the sponsorship event. The invited respondents were randomly sampled among the company's employees. Respondents were motivated to take a part in the survey by the chance to win an iPad Mini in a raffle. In total, 716 usable responses were received, yielding a response rate of $22.4 \%$. The respondents included only the B2B case company's current employees, most of whom had participated in the sponsorship event (i.e., attended the event as guests).

\section{Measures}

The study constructs were measured with existing multi-item (reflective) scales, which were obtained from the literature. All items are listed in the appendix. Project communication quality was measured using five items that were adopted from Hänninen and Karjaluoto (2017). Five items that were related to employees' perceptions of sponsor-event fit were adopted from Speed and Thompson (2000). A subset of a brand equity scale that was developed by Yoo and Donthu (2001) was used to measure employer brand associations. Three items related to employer brand image were adopted from Nguyen and Leblanc (2001). Employer attraction was measured using a four-item scale by Lievens (2007). Organizational identity-related items were adopted from 
David et al. (2005). Organizational culture was measured using a scale from Dawson et al. (2011). The employees' overall satisfaction toward their employer scale was adopted from Ryan et al. (1999). Employees' organizational commitment was measured using five items adopted from Fernandez-Lorez et al. (2016). Finally, three items were used to measure employees' productivity. Two of these items were adopted from Karr-Wisniewski and Lu (2010), and one was from Robertson et al. (2012). Slight modifications to the wording of the original items were made. All the items were measured via seven-point Likert scales, ranging from one (strongly disagree) to seven (strongly agree). Partial least squares with SmartPLS3.2 (Ringle et al., 2015) were used to test the model's relationships. The use of partial least squares (PLS) was considered applicable because this study focused on prediction. Per Hair et al., 2017), factor indeterminacy makes covariance-based structural equation modeling unsuitable for prediction purposes. In addition, as PLS has fewer constraints and statistical specifications than co-variance-based structural equation modeling, PLS is suitable for exploratory studies such as this that examine several new relationships between constructs (Hair et al., 2017, p.23).

\section{Common method bias}

In survey research, common method bias (CMB) can undermine study results (Podsakoff et al., 2003). To minimize its effect, respondents' identities were kept confidential, and the items were mixed in the questionnaire. We also statistically examined whether CMB affected our study results by using the marker variable approach (Malhotra et al., 2006). Three marker variables ("It was easy to understand all the questions in this survey"; "The length of the survey was appropriate"; and "I do not deliberately say anything that hurts someone's feelings"), all of which were measured on seven-point Likert scales, were used to capture potential sources of CMB. These items were expected to be theoretically unrelated to the study constructs. In the PLS model, we linked these items to the three outcome variables (employee satisfaction, 
employee commitment, and employee productivity). The correlations were all below 0.3 , while the path coefficients were near zero and not significant. Thus, CMB is unlikely to be of serious concern.

Results

Table 1 presents the demographic information regarding the sample. Slightly over half $(n=434$, $60.4 \%)$ of the respondents were men. Close to one third (30\%) of the respondents were at 3645 years of age and $28 \%$ at $46-55$ years of age. In terms of their working location, most of the respondents worked in Finland (51\%) or Sweden (21.6\%), and most had been working for over ten years at the company.

\section{"Insert Table 1 about here"}

\section{Measurement model}

The measurement model shown in Table 2 (see also Table 3 for the factor loadings, item means, and standard deviations of the items) met the common standards in terms of reliability and validity as follows: 1) all the composite reliabilities were at 0.772 or greater; 2) the factor loadings were at 0.715 or higher and significant $(p<.01) ; 3)$ the Average Variance Extracted (AVE) values were above $0.5 ; 4$ ) the square root of the AVE was higher than the correlations with other latent variables; and 5) the $R^{2}$ values of the outcome variables were moderate or high (ranging between $0.254-0.651$ ).

\footnotetext{
"Insert Table 2 about here"

"Insert Table 3 about here"
} 
We also controlled the outcome variables of the model by respondents' gender, age, and working experience in the company in years. As these controls had no significant effect $(p>$ 0.05) on the outcome variables, we removed these controls from the subsequent analyses.

\section{Structural model}

The results of the hypotheses tests are shown in Figure 2. Hypotheses 1-6 proposed that the employer brand project (measured as sponsor-event fit and project communication quality) are positively related to organizational culture $(\mathrm{H} 1, \mathrm{H} 3)$, organizational identity $(\mathrm{H} 2 \mathrm{H} 4)$, and employer brand association (H5, H6). All these hypotheses (H1-H6) received support from the data. To begin with, sponsor-event fit had a significant effect on organizational culture $(\mathrm{H} 1: \beta$ $=0.321, p<.001)$, organizational identity $(\mathrm{H} 2: \beta=0.353, p<.001)$, and employer brand association (H5: $\beta=0.311, p<.001$ ), confirming H1, H2, and H5. Similarly, project communication quality exhibited positive effects on organizational culture $(\mathrm{H} 3: \beta=0.408, p<$ $.001)$, organizational identity (H4: $\beta=0.312, p<.001)$, and employer brand association (H6: $\beta=0.282, p<.001$ ), providing support for $\mathrm{H} 3, \mathrm{H} 4$, and $\mathrm{H} 6$. These findings confirm the positive effects of EB activities on organizational culture and identity (Backhaus and Tikoo, 2004) and on brand associations (Keller, 1993). From the sport sponsorship point of view, H1-H6 confirm that EB activities incorporated with sponsorship result in these positive outcomes. In line with earlier studies (Bisvas and Suar, 2016), the relationship between employer brand associations and employer brand image was strong and significant, confirming $\mathrm{H} 7(\beta=0.504, p<.001)$. The relationship between employer brand image and employer attraction (H8) was also strong and positive $(\beta=0.778, p<.001)$, thereby providing support for H8 (Gatewood et al., 1993). In line with the literature, employer attraction had a positive impact on job satisfaction $(\beta=$ 0.451, $p<.001$ ), supporting H9. The positive effects of organizational culture on job satisfaction (e.g. Arnold and Spell, 2006; Jian and Klen, 2000) were also confirmed $(\beta=0.286$, 
$p<.001$ ), supporting H10. We also found support for the less examined relationship between organizational identity and employee job satisfaction (H11), although the effect was small ( $\beta$ $=0.140, p<.001)$. In line with the literature (Fu and Deshpande, 2014), job satisfaction had a strong positive impact on commitment $(\beta=0.708, p<.001)$, thus supporting H12. Finally, H13 proposed that employee organizational commitment has a positive impact on employee productivity. This relationship was confirmed $(\beta=0.550, p<.001)$, supporting H13 (Ali et al., 2010; Deepa et al., 2014).

"Insert Figure 2 about here"

Discussion

The objective of this study was to extend and empirically validate Backhaus and Tikoo's (2004) model on the effects of EB in an organization. This study is thus among the first to attempt to model the effects of EB empirically in a context where EB was used through a sport event sponsorship project. The results supported the developed framework and indicated that sport event sponsorship as an EB activity, which was discussed as sponsor-event fit and project communication quality, has a positive effect on employer brand association as well as on organizational culture and identity, and that EB indirectly improves employees' overall satisfaction, which in turn relates to increased commitment and productivity.

\section{Theoretical contributions}

This study makes two main theoretical contributions. First, this study contributes to the EB literature by empirically validating Backhaus and Tikoo's (2004) conceptual framework in an organization. The results confirm that EB activities have positive effects on employer brand association, as indicated by Keller (1993), and on organizational culture and identity (Backhaus and Tikoo, 2004). We further empirically validated the positive effects between employer 
brand association and employer brand image (Bisvas and Suar, 2016), and between employer brand image and employer attraction (Gatewood et al., 1993). The relationship between employees' overall job satisfaction and employees' organizational commitment was very strong. This finding is supported by Fu and Deshpande (2014), who also confirmed the significant positive effect of job satisfaction on organizational commitment. Finally, employee commitment had a positive effect on employee productivity, which mirrored the results of previous studies (Deepa et al., 2014).

Second, our research contributes to the literature on sport sponsorship by providing a practical means to examining and measuring sport sponsorship as an EB activity and linking it to EB outcomes such as organizational culture and employer brand association; thus linking sport sponsorship and EB literature. Our research model conceptualized sport sponsorship as an EB project consisting of the constructs sponsor-event fit and project communication quality. From the sponsorship perspective, the findings confirm the positive effects of sponsor-event fit on positive sponsorship response, in line with the literature (Hermann et al., 2016; Kim and Na, 2008). Our findings are in line with those of Ali et al. (2010) and Meenaghan et al., (2013), who similarly found a positive relationship between sponsorship projects and organizational culture. In addition, we also confirmed that sponsorship projects improve organizational identity (Hickman et al., 2005; Olejniczak and Aicher, 2010). More specifically, our study is among the first ones to confirm the positive effects of sport-related EB activities on organizational culture and organizational identity among current employees -a relationship proposed in the EB literature (Backhaus and Tikoo,2004) but not widely examined in sport sponsorship context. Finally, sport sponsorship, as an EB activity, positively affected overall employee satisfaction, which was explained jointly through organizational culture, organizational identity, and employer attraction. 


\section{Managerial implications}

Improving an employer's brand has been recognized as an effective method for retaining and attracting the most talented workforce. Successful EB strategies enable companies to gain a competitive edge and therefore secure brand success (Moroko and Uncles, 2008). Previous studies on employers have mainly focused on the external effects of EB; therefore, there has been a lack of understanding regarding what makes an employer's brand attractive to current employees (Maxwell and Knox, 2009).

This study aimed to expand the knowledge of managers regarding EB and sport sponsorship, and it provided an example of how to use EB as a form of sport sponsorship. Additionally, this study showed how sponsorship as a strategic tool can help companies achieve EB objectives. The findings provide several positive outcomes that are beneficial for practicing managers, including increased employee job satisfaction and commitment, improved organizational culture and identity, and a higher level of employer attraction.

One of the most important dimensions to consider from the perspective of practicing managers is to create a sponsorship project strategy that involves current employees effectively (Meenaghan, 2001). Project communication quality is important when aiming to involve an internal audience (Meenaghan, 2001). In addition, the sponsorship target is crucial to employees' evaluations of the sponsor-event fit (Speed and Thompson, 2000). Well-identified sponsorship targets can affect an employee's willingness to participate in sponsorship projects (Hickman et al., 2005). Additionally, when employees perceive project communication positively and have positive views of the fit in sport sponsorship projects, their willingness to participate in such projects increases (Meenaghan, 2001). The results of this study indicated that the case company's surveyed employees evaluated the sponsor-event fit and the project's communication efforts positively. The results also indicated that companies should select a sponsorship target that engenders positive evaluations in the minds of their employees. In 
addition, during the sponsorship process, it is crucial to create a communication strategy that satisfies employees' needs and expands their knowledge of the sponsorship project.

Meenaghan et al. (2013) suggested that the success of the sport sponsorship process can be increased by effectively involving employees in the process. The results of this study aligned with that suggestion. The duration of the sponsorship project in the case company was approximately one year -including different pre-event activities (such as forming teams that competed with each other in how much the team members practiced physically before the event) that aimed to increase employee involvement. The results of this dimension of the study indicated positive impacts on employees' opinions toward the employer. Employees who participated in the activities evaluated the sponsorship project and the company as an employer positively. These results underlined the importance of employee involvement in sport sponsorship projects.

\section{Limitations and future research}

As with any study, our study is not without limitations. The data of this study were based on the convenience sampling method, which causes limitations in generalizing the results. The survey was targeted toward the case company's current employees, and it was sent to 3,200 persons via e-mail, of which 716 responded. The overall number of the case company's personnel is approximately 26,000. Thus, the sample was based on a rather limited group of the employees from that organization. The generalization of the results therefore should be made with caution. The participants might also have had more positive opinions toward the case company as an employer than those who did not participate in the study.

In addition, we used cross-sectional data. Although several steps were made to minimize common method bias, it is always present when the data were collected at only one point in time, and they examined the influence of an EB sponsorship activity on organizational identity 
and culture and employer brand associations. The questionnaire was based on subjective evaluations asking respondents to share their opinions of the sponsorship project and its effects on various factors such as organizational culture and identity, job satisfaction and employee productivity, clearly affects the validity of the results. Specifically, examining issues that typically take long time to cultivate such as organizational culture and identity at one point of time is a clear limitation. Thus, the causal relationships should be validated with a longitudinal research design that would allow for interpreting the results more clearly if the data were collected both before and after the project. A longitudinal approach could also more thoroughly validate the effects of an EB sponsorship activity on the outcomes and therefore could improve both the validity and reliability of this research.

The third limitation refers to the application of Backhaus and Tikoo's (2004) framework for utilizing the internal perspective (i.e. current employees) only. Thus, we encourage future research to develop frameworks that utilize an internal perspective to EB.

It would also be beneficial to test the research model in different cultures, industries, and contexts. Finally, it would be purposeful to investigate how sport sponsorship projects enable companies to achieve external EB goals. A possible research approach would be to investigate how sport sponsorship projects impact employer attraction from the perspective of potential talent. Empirical results from these kinds of studies would expand our knowledge of the concepts of EB and sport sponsorship.

\section{References}

Aaker, D.A. (1991), Managing Brand Equity. Capitalizing on the Value of a Brand Name, The Free Press, New York.

Ali, I., Rehman, K.U., Ali, S.I., Yousaf, J. and Zia, M. (2010), “Corporate social responsibility influences, employee commitment and organizational performance", African Journal of Business Management, Vol. 4 No. 13, pp. 2796-2801. 
Ambler, T. and Barrow, S. (1996), "The employer brand”, Journal of Brand Management, Vol. 4, pp. 185-206.

Arnold, T. and Spell, S.C. (2006), "The relationship between justice and benefits satisfaction", Journal of Business and Psychology, Vol. 20 No. 4, pp. 599-620.

Backhaus, K. and Tikoo, S. (2004), "Conceptualizing and researching employer branding”, Career Development International, Vol. 9 No. 5, pp. 501-517.

Berthon, P., Ewing, M. and Hah, L.L. (2005), "Captivating company: dimensions of attractiveness in employer branding”, International Journal of Advertising, Vol. 24 No. 2, pp. 151-172.

Bisvas, M.K. and Suar, D. (2016), “Antecedents and consequences of employer branding”, Journal of Business Ethics, Vol. 136 No. 1, pp. 57-72.

Chambers, E.G., Foulton, M., Handfield-Jones, H., Hankin, S.M. and Michaels, E.G. (1998), “The war for talent", The McKinsey Quarterly, Vol. 3, p. 44-57.

Chapman, D.S., Uggerslev, K.L., Carroll, S.A., Piasentin, K.A. and Jones, D.A. (2005), “Applicant attraction to organizations and job choice: A meta-analytic review of the correlates of recruiting outcomes", Journal of Applied Psychology, Vol. 90, pp. 928-944.

Chhabra, N.K. and Sharma, S. (2014), "Employer branding: strategy for improving employer attractiveness", International Journal of Organizational Analysis, Vol. 22 No. 1, pp. 4860.

Cunningham, S., Cornwell, T.B. and Coote, L.V. (2009), "Expressing identity and shaping image: the relationship between corporate mission and corporate sponsorship", Journal of Sport Management, Vol. 23 No. 1, pp. 65-86.

David, P., Kline, S. and Dai, Y. (2005), “Corporate social responsibility practices, corporate identity, and purchase intention: a dual-process model", Journal of Public Relations Research, Vol. 17 No. 3, pp. 291-313. 
Dawson, M., Abbott, J. and Shoemaker, S. (2011), “The hospitality culture scale: a measure organizational culture and personal attributes", International Journal of Hospitality Management, Vol. 30 No. 2, pp. 290-300.

Deepa, E., Palaniswamy, R. and Kuppusamy, S. (2014), "Effect of performance appraisal system in organizational commitment, job satisfaction and productivity", Journal of Contemporary Management Research, Vol. 8 No. 1, pp. 72-82.

Deshpande, R. and Webster Jr, F.E. (1989), "Organizational culture and marketing: defining the research agenda", Journal of Marketing, Vol. 53 No. 1, pp. 3-15.

Dutton, J. E., Duckerich, J. M. and Harquail, C.V. (1994), “Organizational images and member identification", Administrative Science Quarterly, Vol. 39 No. 2, pp. 239-263.

Farrelly, F.J. and Greyser, S.A. (2007), "Sports sponsorship to rally the home team”, Harvard Business Review, Vol. 85 No. 9, pp. 22-25.

Fernandez-Lores, S., Gavilan, D., Avello, M. and Blasco, F. (2016), “Affective commitment to the employer brand: development and validation of a scale", BRQ Business Research Quarterly, Vol. 19 No. 1, pp. 40-54.

Fu, W. and Deshpande, S.P. (2014), "The Impact of Caring Climate, Job Satisfaction, and Organizational Commitment on Job Performance of Employees in a China's Insurance Company", Journal of Business Ethics, Vol. 124, pp. 339-349.

Gatewood, R.D., Gowan, M.A. and Lautenschlager, G.J. (1993), “Corporate image, recruitment image and initial job choice decisions", Academy of Management Journal, Vol. 36 No. 2, pp. 414-427.

Hair, J.F. Jr., Hult, G.T.M., Ringle, C.M. and Sarstedt, M. (2017), A Primer on Partial Least Squares Structural Equation Modeling (PLS-SEM) (2 ${ }^{\text {nd }}$ ed.), Sage Publications, Thousand Oaks. 
Hellriegel, D., Slocum, J. and Woodman, R. (1998), Organizational Behavior, South-Western College Publishing, Cincinnati.

Herrmann, J.L., Kacha, M., and Derbaix, C. (2016), "I support your team, support me in turn!" The driving role of consumers' affiliation with the sponsored entity in explaining behavioral effects of sport sponsorship leveraging activities. Journal of Business Research, Vol. 69 No. 2, pp. 604-612.

Herzberg, F., Mausner, B., Peterson, R.O. and Capwell, D.F. (1957), Job Attitudes: Review of Research and Opinion, Psychological Service of Pittsburgh, Pittsburg, PA.

Heskett, J.L, Jones T.O., Loveman, G.W., Sasser, E.W. and Schlesinger, L.A. (1994), "Putting the service-profit chain to work", Harvard Business Review, Vol. 72 No. 2, pp. 164-170.

Hickman, T.M., Lawrence, K.E. and Ward, J.C. (2005), "A social identities perspective on the effects of corporate sport sponsorship on employees", Sport Marketing Quarterly, Vol. 14 No. 3, pp. 148-157.

Hänninen, N. and Karjaluoto, H. (2017), ”The effect of marketing communication on business relationship loyalty", Marketing Intelligence \& Planning, Vol. 35 No. 4, pp. 458-472. [s]

Judge, T.A. and Cable, D.M. (1997), "Applicant personality, organizational culture, and organization attraction”, Personnel Psychology, Vol. 50 No. 2, pp. 359-394.

Kahn, W.A. (1992), "To be fully there: psychological presence at work", Human Relations, Vol. 45 No. 4, pp. 321-349.

Kang, M., and Sung, M. (2017), "How symmetrical employee communication leads to employee engagement and positive employee communication behaviors: The mediation of employee-organization relationships", Journal of Communication Management, Vol. 21 No. 1, pp. 82-102. 
Karr-Wisniewski, P. and Lu, Y. (2010), "When more is too much: operationalizing technology overload and exploring its impact on knowledge worker productivity", Computers in Human Behavior, Vol. 26 No. 5, pp. 1061-1072.

Keller, K.L. (1993), “Conceptualizing, measuring, and managing customer-based brand equity”, Journal of Marketing, Vol. 57 No. 1, pp. 1-22.

Kim, Y-J. and Na, J-H. (2007), "Effects of celebrity athlete endorsement on attitude towards the product: the role of credibility, attractiveness and the concept of congruence", International Journal of Sports Marketing and Sponsorship, Vol. 8 N. 4, pp .23-33.

Kress, N., (2005), "Engaging your employees through the power of communication", Workspan, Vol. 48 No. 5, pp. 26-36.

Kristof, A.L. (1996), "Person-organization fit: an integrative review of its conceptualizations, measurement, and implications", Personnel Psychology, Vol. 49 No. 1, pp. 1-49.

Kristof-Brown, A.L., Zimmerman, R.D. and Johnson, E.C. (2005), "Consequences of individuals' fit at work: A meta-analysis of person-job, person-organization, persongroup, and person-supervisor fit”, Personnel Psychology, Vol. 58 No. 2, pp. 281-342.

Lievens, F. (2007), "Employer branding in the Belgian Army: the importance of instrumental and symbolic beliefs for potential applicants, actual applicants, and military employees", Human Resource Management, Vol. 46 No. 1, pp. 51-69.

Malhotra, N.K., Kim, S.S. and Patil, A. (2006), "Common method variance in IS research: A comparison of alternative approaches and a reanalysis of past research", Management Science, Vol. 52 No. 12, pp. 1865-1883.

Martin, G., Gollan, P.J. and Grigg, K. (2011), "Is there a bigger and better future for employer branding? Facing up to innovation, corporate reputations and wicked problems in SHRM", The International Journal of Human Resource Management, Vol. 22 No. 17, pp. $3618-3637$. 
Maxwell, R. and Knox, S. (2009), "Motivating employees to 'live the brand': a comparative case study of employer brand attractiveness within the firm", Journal of Marketing Management, Vol. 25 No. 9-10, pp. 893-907.

McKinnon, L.J., Harrison, L.G., Chow, W.C. and Wu, A. (2003), “Organizational culture: association with commitment, job satisfaction, propensity to remain and information sharing in Taiwan”, International Journal of Business Studies, Vol. 11 No. 1, pp. 25-44.

Meenaghan, T. (2001), “Understanding sponsorship effects”, Psychology and Marketing, Vol. 18 No. 2, pp. 95-122.

Meenaghan, T., McLoughlin, D. and McCormack, A. (2013), "New challenges in sponsorship evaluation actors, new media, and the context of praxis", Psychology \& Marketing, Vol. 30 No. 5, pp. 444-460.

Meyer, J.P. and Herscovitch, L. (2001), “Commitment in the workplace: toward a general model", Human Resource Management Review, Vol. 11 No. 3, pp. 299-326.

Miller, K.I. and Monge, P.R. (1986), "Participation, satisfaction, and productivity: a metaanalytic review", Academy of Management Journal, Vol. 29 No. 4, pp. 727-753.

Moroko, L. and Uncles, M.D. (2008), “Characteristics of successful employer brands”, Journal of Brand Management, Vol. 16 No. 3, pp. 160-175.

Mueller, C.W., Wallace, J.E. and Price, J.L. (1992), “Employee commitment: resolving some issues", Work and Occupations, Vol. 19 No. 3, pp. 211-236.

Nguyen, N. and Leblanc, G. (2001), “Corporate image and corporate reputation in customers' retention decisions in services", Journal of Retailing and Consumer Services, Vol. 8 No. 4, pp. 227-236.

Nystrom, P.C. (1993), “Organizational cultures, strategies, and commitments in health care organizations", Health Care Management Review, Vol. 18 No. 1, pp. 43-49. 
Olejniczak, M. and Aicher, T.J. (2010), “Conceptual framework of sponsorship's relationship with components of organizational culture", International Journal of Sport Management, Recreation and Tourism, Vol. 6 No. b, pp. 18-36.

Pasmore, W.A. and Fagans, M.R. (1992), "Participation, individual development, and organizational change: A review and synthesis”, Journal of Management, Vol. 18 No. 2 , pp. 375-397.

Podsakoff, P.M., MacKenzie, S.B., Lee, J.-Y. and Podsakoff, N.P. (2003), "Common method biases in behavioral research: A critical review of the literature and recommended remedies", Journal of Applied Psychology, Vol. 88 No. 5, pp. 879-903.

Ravasi, D. and Schultz, M. (2006), "Responding to organizational identity threats: Exploring the role of organizational culture", Academy of Management Journal, Vol. 49 No. 3, pp. 433-458.

Ringle, C.M., Wende, S. and Becker, J.-M. (2015), SmartPLS 3, Retrieved from website: http://www.smartpls.com.

Robertson, I.T., Birch, A.J. and Cooper, C.L. (2012), "Job and work attitudes, engagement and employee performance: where does psychological well-being fit in?", Leadership \& Organization Development Journal, Vol. 33 No. 3, pp. 224-232.

Ryan, A., Chan, D., Ployhart, R.E. and Slade, L.A. (1999), "Employee attitude surveys in a multinational organization: considering language and culture in assessing measurement equivalence", Personnel Psychology, Vol. 52 No. 1, pp. 37-58.

Scholl, R.W. (1981), "Differentiating organizational commitment from expectancy as a motivating force”, Academy of Management Review, Vol. 6 No. 4, pp. 589-599.

Speed, R. and Thompson, P. (2000), “Determinants of sports sponsorship response”, Journal of the Academy of Marketing Science, Vol. 28 No. 2, pp. 226-238. 
Staw, B.M. (1981), "The escalation of commitment to a course of action", Academy of Management Review, Vol. 6 No. 4, pp. 577-587.

Syptak, J.M., Marsland, D.W. and Ulmer, D. (1999), "Job satisfaction: putting theory into practice", Family Practice Management, Vol. 6 No. 9, pp. 26-31.

Theurer, C.P., Tumasjan, A., Welpel, I.M. and Lievens, F. (2018), "Employer branding: A brand equity-based literature review and research agenda", International Journal of Management Reviews, Vol. 20, pp. 155-179.

Verquer, M.L., Beehr, T.A. and Wagner, S.H. (2003), "A meta-analysis of relations between person-organization fit and work attitudes", Journal of Vocational Behavior, Vol. 63 No. 3, pp. 473-489.

Welch, M. (2011), "The evolution of the employee engagement concept: communication implications", Corporate Communications: An International Journal, Vol. 16, No. 4, pp. $328-346$

Wheeler, A.R., Buckley, M.R., Halbesleben, J.R., Brouer, R.L. and Ferris, G.R. (2005), “The elusive criterion of fit revisited: toward an integrative theory of multidimensional fit", Research in Personnel and Human Resources Management, Vol. 24, pp. 265-304.

Wiley, J.W., Kowske, B.J., and Herman, A.E. (2010), "Developing and validating a global model of employee engagement", in Albrecht, S.L. (Ed.), Handbook of Employee Engagement: Perspectives, Issues, Research and Practice, Edward Elgar, Cheltenham.

Woodman, R.W. (1989), “Organizational change and development: new arenas for inquiry and action”, Journal of Management, Vol. 15 No. 2, pp. 205-228.

Yoo, B. and Donthu, N. (2001), "Developing and validating a multidimensional consumerbased brand equity scale", Journal of Business Research, Vol. 52 No. 1, pp. 1-14.

\section{LIST OF TABLES}


Table 1 Sample profile

\begin{tabular}{|c|c|c|}
\hline & $\mathbf{N}$ & $\%$ \\
\hline \multicolumn{3}{|l|}{ Gender } \\
\hline Male & 434 & 60.6 \\
\hline Female & 282 & 39.4 \\
\hline Total & 716 & 100.0 \\
\hline \multicolumn{3}{|l|}{ Age } \\
\hline $18-25$ & 25 & 2.5 \\
\hline $26-35$ & 177 & 24.7 \\
\hline $36-45$ & 215 & 30.0 \\
\hline $46-55$ & 203 & 28.4 \\
\hline 56 or over & 96 & 13.4 \\
\hline Total & 716 & 100.0 \\
\hline \multicolumn{3}{|c|}{ Working experience in the case company } \\
\hline Less than 2 years & 96 & 13.4 \\
\hline $2-5$ years & 91 & 12.7 \\
\hline $5-10$ years & 100 & 14.0 \\
\hline Over 10 years & 429 & 59.9 \\
\hline Total & 716 & 100.0 \\
\hline \multicolumn{3}{|l|}{ Working location } \\
\hline Finland & 365 & 51.0 \\
\hline Sweden & 154 & 21.5 \\
\hline China & 29 & 4.0 \\
\hline Russia & 27 & 3.8 \\
\hline Germany & 27 & 3.8 \\
\hline Czech Republic & 26 & 3.6 \\
\hline Other & 88 & 12.3 \\
\hline Total & 716 & 100.0 \\
\hline
\end{tabular}

Table 2 Average Variance Extracted (AVE), factor correlations, and square root of AVE (diagonal).

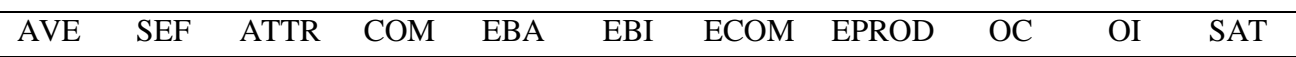




\begin{tabular}{lllllllllllll}
\hline SEF & 0.832 & $\mathbf{0 . 9 1 2}$ & & & & & & & & & \\
ATTR & 0.783 & 0.546 & $\mathbf{0 . 8 8 5}$ & & & & & & & & \\
COM & 0.779 & 0.713 & 0.564 & $\mathbf{0 . 8 8 3}$ & & & & & & & \\
EBA & 0.539 & 0.511 & 0.495 & 0.503 & $\mathbf{0 . 7 3 4}$ & & & & & & \\
EBI & 0.792 & 0.586 & 0.778 & 0.587 & 0.504 & $\mathbf{0 . 8 9 0}$ & & & & & \\
ECOM & 0.769 & 0.471 & 0.776 & 0.464 & 0.419 & 0.609 & $\mathbf{0 . 8 7 7}$ & & & & \\
EPROD & 0.832 & 0.322 & 0.512 & 0.352 & 0.289 & 0.435 & 0.550 & $\mathbf{0 . 9 1 2}$ & & & \\
OC & 0.659 & 0.612 & 0.769 & 0.637 & 0.468 & 0.793 & 0.627 & 0.456 & $\mathbf{0 . 8 1 2}$ & & \\
OI & 0.626 & 0.575 & 0.675 & 0.563 & 0.444 & 0.723 & 0.564 & 0.440 & 0.780 & $\mathbf{0 . 7 9 1}$ & \\
SAT & 0.846 & 0.486 & 0.766 & 0.494 & 0.363 & 0.678 & 0.708 & 0.528 & 0.742 & 0.668 & $\mathbf{0 . 9 2 0}$ \\
\hline Means & & 5.33 & 5.88 & 5.45 & 6.14 & 5.40 & 6.04 & 6.12 & 5.22 & 5.71 & 5.55 \\
s.d. & & 1.42 & 1.19 & 1.41 & 1.28 & 1.24 & 1.25 & 0.94 & 1.31 & 1.07 & 1.10 \\
\hline
\end{tabular}

Notes:

SEF - Sponsor-event fit

ATTR - Employer attraction

COM - Project communication quality

EBA - Employer brand association

EBI - Employer brand image

ECOM - Employees' organizational commitment

EPROD - Employee productivity

$\mathrm{OC}$ - Organizational culture

OI - Organizational identity

SAT -Overall job satisfaction 


\section{LIST OF FIGURES}

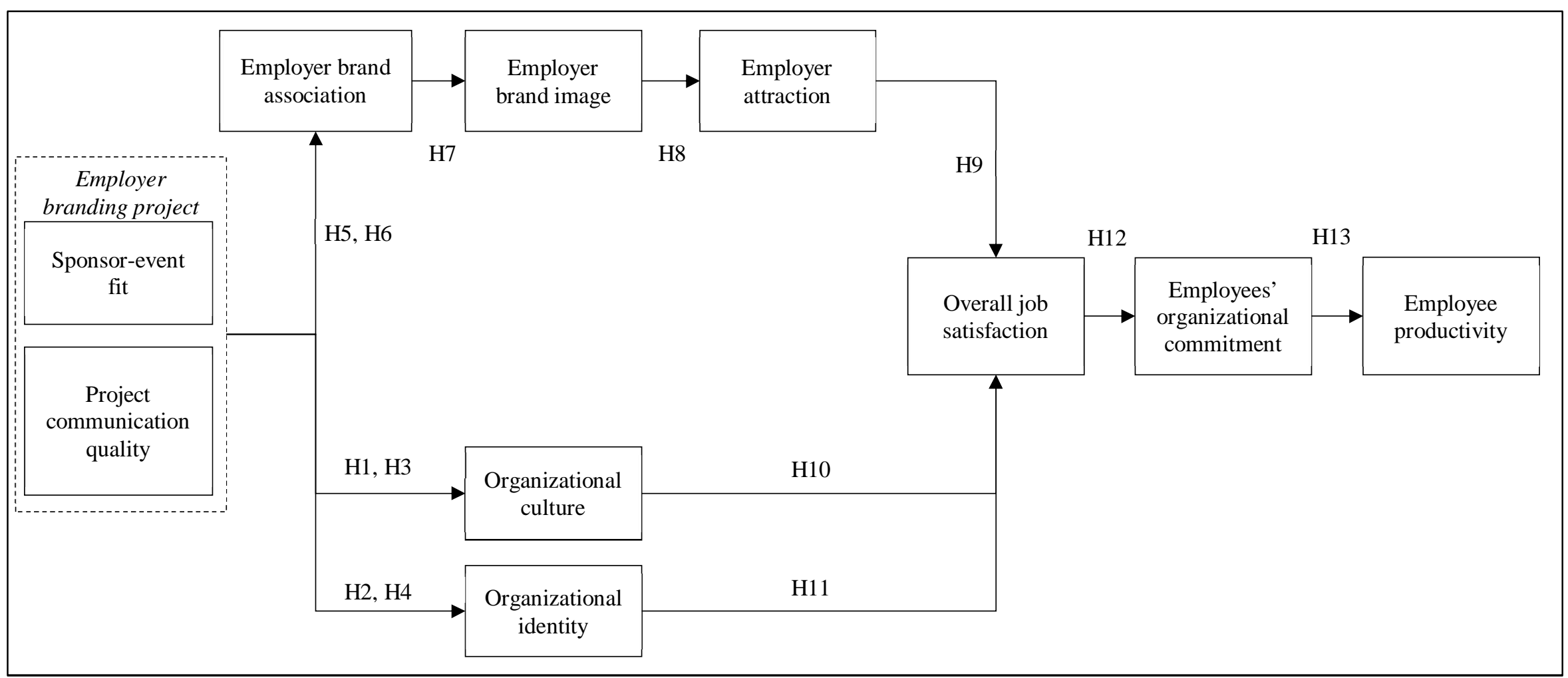

Figure 1 Research model and hypotheses 


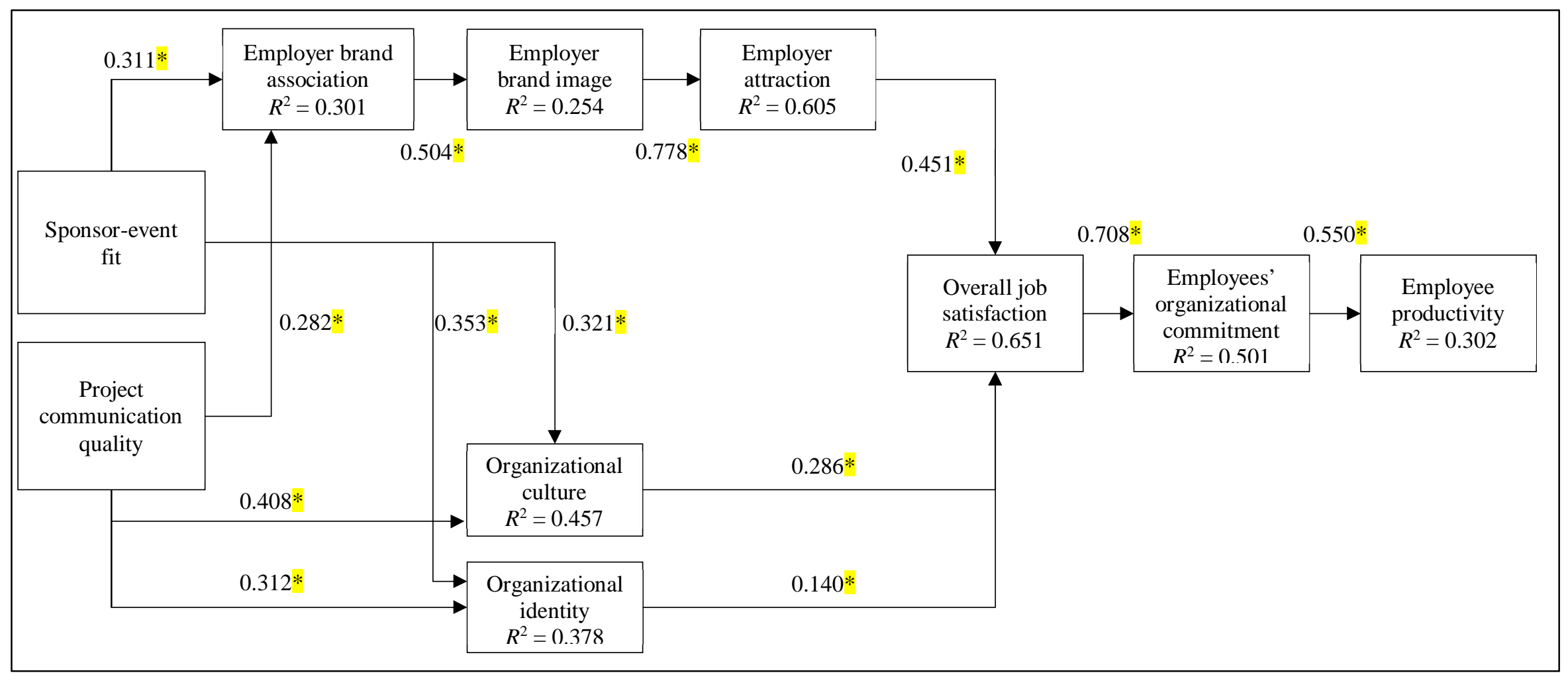

Figure 2 Structural model results

Notes:

Two-tailed test $(* p<0.001)$ 


\section{APPENDIX}

Table 3 List of survey items

\begin{tabular}{|c|c|c|c|}
\hline & $\begin{array}{c}\text { Factor } \\
\text { loadings }\end{array}$ & Mean & $\mathrm{SD}^{\mathrm{a}}$ \\
\hline \multicolumn{4}{|l|}{ Sponsor-event fit $\left(\mathrm{CR}^{\mathrm{b}}=0.961\right)$} \\
\hline 1. There is a logical connection between the case company and the event. & 0.905 & 5.30 & 1.43 \\
\hline 2. The image of the event and the image of the case company are similar. & 0.903 & 5.04 & 1.42 \\
\hline 3. The case company and the event stand for similar values. & 0.925 & 5.21 & 1.36 \\
\hline 4. The case company and the event fit together well. & 0.927 & 5.57 & 1.41 \\
\hline 5. It makes sense that the case company sponsors the event. & 0.902 & 5.54 & 1.49 \\
\hline \multicolumn{4}{|l|}{ Project communication quality $\left(\mathrm{CR}^{\mathrm{b}}=0.955\right)$} \\
\hline 1. The event has been communicated well in the case company. & 0.871 & 5.74 & 1.24 \\
\hline $\begin{array}{l}\text { 2. The case company has provided useful information for me concerning to the } \\
\text { event. }\end{array}$ & 0.903 & 5.32 & 1.43 \\
\hline $\begin{array}{l}\text { 3. The case company's communications concerning to the event has been } \\
\text { efficient. }\end{array}$ & 0.926 & 5.43 & 1.32 \\
\hline 4. The case company has actively communicated issues related to the event. & 0.892 & 5.47 & 1.39 \\
\hline $\begin{array}{l}\text { 5. The case company has used suitable communication channels for me } \\
\text { concerning to the event. }\end{array}$ & 0.904 & 5.23 & 1.38 \\
\hline $\begin{array}{l}\text { 6. Event communication has made me interested about the Nordic Ski World } \\
\text { Championships and the case company's presence there. }\end{array}$ & 0.795 & 5.20 & 1.72 \\
\hline \multicolumn{4}{|l|}{ Organizational culture $\left(\mathrm{CR}^{\mathrm{b}}=0.931\right)$} \\
\hline 1. The case company supports, empowers and rewards their employees. & 0.861 & 5.06 & 1.34 \\
\hline 2. The case company is employee focused. & 0.882 & 5.05 & 1.33 \\
\hline 3. The case company constantly reinforces the company's culture. & 0.820 & 5.17 & 1.24 \\
\hline 4. Training is important within the organization. & 0.798 & 5.41 & 1.28 \\
\hline 5. The case company has a focus on employee retention. & 0.802 & 4.54 & 1.46 \\
\hline $\begin{array}{l}\text { 6. The case company is an organization where there are many opportunities to } \\
\text { relocate. }\end{array}$ & 0.716 & 5.35 & 1.38 \\
\hline $\begin{array}{l}\text { 7. The case company is an organization where employees do more than is } \\
\text { required of them (dropped). }\end{array}$ & $\mathrm{n} / \mathrm{a}$ & 5.31 & 1.21 \\
\hline 8. The case company aims to do what is right. & 0.795 & 5.85 & 1.20 \\
\hline \multicolumn{4}{|l|}{ Organizational identity $\left(\mathrm{CR}^{\mathrm{b}}=0.921\right)$} \\
\hline \multicolumn{4}{|l|}{ (please rate the case company in the light of following attributes): } \\
\hline 1. Not expert - Expert & 0.808 & 5.83 & 1.03 \\
\hline 2. Not compassionate - Compassionate & 0.735 & 5.03 & 1.26 \\
\hline 3. Not innovative - Innovative & 0.751 & 5.55 & 1.15 \\
\hline 4. Not sincere - Sincere & 0.776 & 5.63 & 1.15 \\
\hline 5. Not trustworthy - Trustworthy & 0.817 & 5.81 & 1.10 \\
\hline 6. Not skilled - Skilled & 0.837 & 5.94 & 0.93 \\
\hline 7. Not experienced - Experienced & 0.811 & 6.17 & 0.91 \\
\hline \multicolumn{4}{|l|}{ Employer brand association $\left(\mathrm{CR}^{\mathrm{b}}=0.772\right)$} \\
\hline 1. Some characteristics of the case company come to mind quickly. & 0.886 & 5.82 & 1.27 \\
\hline 2. I have difficulty in imagining the case company in my mind & 0.564 & 5.95 & 1.54 \\
\hline 3. I can quickly recall the symbol or logo of the case company. & 0.717 & 6.65 & 1.01 \\
\hline \multicolumn{4}{|l|}{ Employer brand image $\left(\mathrm{CR}^{\mathrm{b}}=0.919\right)$} \\
\hline 1. I have a good impression of the case company as an employer. & 0.907 & 5.81 & 1.17 \\
\hline
\end{tabular}


2. In general the case company has a good image as an employer in the minds

of employees.

3. I believe that the case company has a better image than its competitors.

Employer attraction $\left(\mathrm{CR}^{\mathrm{b}}=0.935\right)$

4. For me, the case company is a good place to work.

5 . The case company is attractive to me as a place for employment.

$0.927 \quad 5.88 \quad 1.12$

6. I am interested in learning more about the case company.

$0.753 \quad 5.74 \quad 1.31$

7. A job at the case company is very appealing to me.

0.932

5.78

1.26

Overall job satisfaction $\left(\mathrm{CR}^{\mathrm{b}}=0.917\right)$

1. Considering everything, how satisfied are you with the content of your job.

$\begin{array}{lll}0.903 & 5.59 & 1.06\end{array}$

2. Considering everything, how would you rate your overall satisfaction toward the case company as an employer at the present time.

Organizational commitment $\left(\mathrm{CR}^{\mathrm{b}}=0.943\right)$

1. My commitment to the case company is long-term oriented.

2. I desire to work for the case company for a long time.

3. I would feel sad if I had to leave the case company.

0.844

$5.75 \quad 1.47$

4. I am loyal to the case company.

5. I feel myself a part of the case company and I wish to remain like this in the future.

Employee productivity $\left(\mathrm{CR}^{\mathrm{b}}=0.937\right)$

1. Overall I feel I perform my job effectively.

2. Overall I feel I perform my job productively.

Notes:

${ }^{\mathrm{a}}=\mathrm{SD}-$ Standard Deviation

$\mathrm{b}=\mathrm{CR}-$ Composite Reliability

${ }^{\mathrm{c}}=$ Reverse coded

All items were measured on 7 point-scales ranging from 1=strongly disagree

to $7=$ strongly agree 